\title{
The influence of futures work on public policy and sustainability
}

Chris Riedy

Dr Chris Riedy is a Research Director at the Institute for Sustainable Futures, University of Technology, Sydney.

Postal: PO Box 123 Broadway NSW 2007 Australia.

Tel: +61 29514 4964. Fax: +61 295144941.

Email: criedy@uts.edu.au

\section{Abstract}

\section{Purpose}

This paper draws on a global scan of futures literature undertaken for the State of Play in the Futures Field (SOPIFF) project to investigate the contribution of futures work to averting looming sustainability challenges and suggest new strategies for influencing policy and practice.

\section{Design/methodology/approach}

The SOPIFF project used an Integral meta-scanning framework to review publicly available futures material, providing a rich source of material to use in assessing the influence achieved by futures work. The framework categorises futures work according to organisational type, social interests, methods, domains and geographic location.

\section{Findings}

On the whole, the influence achieved by futures work is disappointing given that many futurists are strongly committed to bringing about more desirable futures. Some qualified success stories include science and technology foresight, getting sustainability challenges onto the social agenda and small-scale, distributed initiatives.

\section{Research limitations/implications}

Limitations of the scanning process include heavy reliance on publicly available material, prioritisation of breadth over depth of analysis and the physical and cultural location of the researchers. Future iterations of the research should go beyond public material, undertake deeper analysis of scanning hits and draw in more non-Western and non-English work.

\section{Practical implications}

The paper proposes four strategies for increasing the influence of futures work: methodological renewal, political engagement, individual capacity building and participatory approaches.

\section{Originality/value}

The paper uses the recently developed Integral meta-scanning framework to provide a novel view of the futures field. The findings will be of value to foresight practitioners that are seeking to influence public policy and sustainability.

\section{Keywords}

State of Play in the Futures Field; sustainability; influence. 


\section{Paper type}

Viewpoint

\section{Introduction}

It is abundantly clear in this first decade of the $21^{\text {st }}$ Century that we face a series of unprecedented environmental and social challenges that, in combination, threaten the sustainability of human civilisation. These challenges include the threat of dangerous climate change, unsustainable growth in resource use, loss of supporting ecosystems, extreme inequity between and within nations, severe poverty across much of the planet and management of technological risks associated with nuclear weapons, artificial intelligence and nanotechnology. Slaughter (2002) calls the combination of these and other bleak trends our 'civilisational challenge'.

Futures thinking should be one of our key defences against this civilisational challenge, allowing us to anticipate dangerous trends, identify desirable futures and respond appropriately. Foresight is needed to steer a path towards a sustainable civilisation. Futures work can fulfil this role by influencing decision-makers in positions of power to deliver policy and action consistent with a sustainable future or by contributing to the establishment of social movements that bypass existing decision-makers and power structures. In this paper, I examine how successful futures work has been in influencing policy and action, in placing new issues on the social agenda and in furthering the human quest for sustainability.

While all policy-making considers the future, formally or informally (Glenn et al., 2001), not all futures work sets out to explicitly influence policy and practice. In this paper, I am concerned with the question of whether specific futures projects that have sought to influence policy and practice or to get new issues on the social agenda have achieved that aim.

This raises the question of how to measure influence. Glenn et al. $(2001$, p. 186) identify two alternative measures of successful influence:

Some people believe that the success of futures work is best measured by whether consciousness has been raised/changed or not. Others insist that is not enough; foresight has to be acted upon for it to be deemed 'successful'.

In this paper, I look for examples of both kinds of influence but particularly the latter, given that action is clearly needed to avert looming sustainability challenges. For evidence, I draw on an international review of futures literature undertaken for the State of Play in the Futures Field (SOPIFF) project, funded by the Foundation for the Future. The SOPIFF project used an Integral meta-scanning framework to review publicly available futures material. ${ }^{1}$ The review was supplemented by a small number of interviews with futurists to clarify particular issues. The ambitious global scope of the project created some important limitations. First, the heavy reliance on publicly available material means that important non-public applications of foresight to influence public policy will have been missed. The data sheds no light on the effectiveness of futurists working behind the scenes to facilitate a response to sustainability challenges. Second, the scan prioritised breadth over depth. The reviewers were most interested in identifying broad patterns in the data, rather than deeply investigating all the material. A deeper reading of the collected scans could reveal different patterns. Finally, the physical and cultural location of the researchers meant that the review was dominated by futures and foresight work in the Western world and the English language. Despite these limitations, the SOPIFF project does provide valuable insights into the influence achieved by futures work. The review material is accessible at http://www.thinkingfutures.net/sopiff. 


\section{Criticism of the influence of futures work}

The SOPIFF project identified multiple critiques of the influence achieved by futures work (e.g. Cameron et al., 2006; Glenn et al., 2001; Hayward, 2003; Kapoor, 2001; Miles and Keenan, 2003; Rejeski and Olson, 2006; Slaughter, 2007; Stevenson, 2001; van der Duin et al., 2006). I have focused here on some of the more recent, powerful and illuminating critiques.

In a provocative recent article, Rejeski and Olson (2006) ask: 'Has futurism failed'? They argue that: 'We pay less attention to the long run today than we did in the 1970s' (Rejeski and Olson, 2006, p. 21). In their view, the influence achieved by futures work has fallen from its peak in the 1970s. Likewise, Slaughter $(2007$, p. 748$)$ finds that:

On the whole, humankind appears to be proceeding along business-as-usual lines, as though its collective prospects remained open and unthreatened. It has been suggested, therefore, that we are, on the whole, still 'sleep walking' our way into the future.

In a similar vein, Stevenson $(2001$, p. 666) examines the state of futures work and finds that a common limitation of scenarios 'is the failure to link them directly to decision and action. This can result in having all the work sit to gather dust'.

Glenn et al. (2001) summarise a Millennium Project report on Factors Required for Successful Implementation of Futures Research in Decision-Making. According to one of the research participants:

Unfortunately, policymaking is usually impervious to futures studies. Predictions of the future can be picked apart and disregarded. Time horizons can be impossibly short...Much futures work seems to be just some person having a bright idea which may or may not be used to form policy and guide action (most of the material I have been sent has been of failures, not successes; or of possible, but certainly not conclusive, successes) (Glenn et al., 2001, p. 188).

Kapoor (2001, p. 161) provides a particularly powerful critique of the influence of futures work, concluding that: 'Future studies.... is oriented little towards policy and praxis and, consequently, has had little impact on the course of changes in and the driving forces shaping the real world'. Further, he argues that:

For a variety of reasons, which include a narrow focus, the inability to predict with precision, and the frequent exclusion from decision-making structures, future studies is of little consequence to the colossal changes taking place in the real world (Kapoor, 2001, p. 166).

These general critiques position futures work as a marginal activity or academic exercise, with little influence on the powerful institutional decision-making structures that shape our world and create our future. This should be of great concern to futurists, many of whom are actively seeking to create change towards more desirable futures.

Critics of the influence of future work have suggested numerous reasons for the general failure of futures work to influence policy and praxis. Table 1 integrates and summarises explanations for the lack of influence of futures work. While some of these explanations relate to the cultural and contextual settings within which futurists operate, others relate to the quality of futures work and the approach taken by futurists. These explanations point to ways that futures work might be improved to increase its potential to influence policy and praxis. I will 
turn to possible improvements later in the paper, after considering what can be learnt from the successes achieved by futurists. 


\begin{tabular}{|c|c|}
\hline $\begin{array}{l}\text { Reason for lack of } \\
\text { influence }\end{array}$ & Description \\
\hline $\begin{array}{l}\text { Much futures work is } \\
\text { shallow and of poor } \\
\text { quality }\end{array}$ & $\begin{array}{l}\text { Much futures work is shallow, linear, dominated by pop futurism } \\
\text { and techno-futures and concerned with the perpetuation of } \\
\text { Western worldviews (Kapoor, 2001; Slaughter, 2007; Stevenson, } \\
\text { 2001). It deals primarily with exterior trends and ignores interiors. It } \\
\text { is often based on inadequate, partial information. This poor quality } \\
\text { work does little to open up new, more desirable futures. Further, it } \\
\text { inevitably delivers wrong predictions, which undermine confidence } \\
\text { in futures work. In addition, this work ignores the alternative } \\
\text { perspectives of the majority of the world's people. As Kapoor } \\
\text { (2001, p. 161) puts it: 'Future studies is dominated by western, } \\
\text { instrumental perspectives and by pro-rich and corporate concerns, } \\
\text { and it ignores alternative cultural perspectives as well as the } \\
\text { interests and concerns of the majority of human beings'. This } \\
\text { excludes a rich source of creativity and makes futures work } \\
\text { superfluous to most people. }\end{array}$ \\
\hline $\begin{array}{l}\text { Links to specific actions } \\
\text { are difficult to make }\end{array}$ & $\begin{array}{l}\text { While a futures exercise may provide valuable insights when it is } \\
\text { undertaken, the common failure to do the hard work of translating } \\
\text { those insights into a specific action plan means that real } \\
\text { organisational change is rarely achieved (Stevenson, 2001). When } \\
\text { participants return to their everyday concerns, insights are readily } \\
\text { forgotten unless there are specific actions to take forward. For } \\
\text { example, in their review of the UK Foresight Programme, Miles and } \\
\text { Keenan (2003, p. } 45 \text { ) criticised the less influential second round of } \\
\text { foresight activities under the Programme for 'a lack of clear linkages } \\
\text { to policy timetables and levers'. In some cases, it is difficult to know } \\
\text { where to start to initiate a transition to a sustainable future. In } \\
\text { many other cases, it is difficult to identify and assign responsibilities } \\
\text { and funding for actions when numerous parties are involved (Glenn } \\
\text { et al., 2001). }\end{array}$ \\
\hline $\begin{array}{l}\text { The dominant Western } \\
\text { worldview reinforces } \\
\text { short-term thinking }\end{array}$ & $\begin{array}{l}\text { As discussed by Slaughter (2007), an innate human biological } \\
\text { tendency to prioritise the short-term is reinforced by a pervasive } \\
\text { Western worldview that encourages instant gratification and denial } \\
\text { of future limits. This combination of systemic and cultural factors } \\
\text { makes it very difficult for futures work to find traction. Futures } \\
\text { work remains a 'cultural sideshow' (Slaughter, 2008a, p. 91). This } \\
\text { position is supported by Tonn's ( } 2007 a \text { ) intriguing finding that } \\
\text { democracy and wealth are negatively correlated with future- } \\
\text { orientedness. It is the comfortable, Western democracies that are } \\
\text { least likely to concern themselves with the future. The short } \\
\text { political cycle in most democracies strengthens the prioritisation of } \\
\text { immediate political action over long-term vision (Glenn et al., } \\
\text { 2001). }\end{array}$ \\
\hline $\begin{array}{l}\text { Futurists do not engage } \\
\text { sufficiently with the }\end{array}$ & $\begin{array}{l}\text { As noted by Kapoor (2001, p. 162), 'futurists have only interpreted } \\
\text { the world in various ways! The point, however, is to change it'. }\end{array}$ \\
\hline
\end{tabular}




\begin{tabular}{|c|c|}
\hline political context & $\begin{array}{l}\text { Futures thinking often threatens those who benefit from business } \\
\text { as usual and its conclusions will be resisted. For example, in their } \\
\text { review of the UK Foresight Programme, Cameron et al (2006, p. 4) } \\
\text { found that when 'conclusions raise challenging issues for public } \\
\text { policy the Programme has come under some pressure'. Decision- } \\
\text { making is a political act and futurists that wish to achieve influence } \\
\text { cannot divorce themselves from the political context. An activist } \\
\text { orientation is required to achieve many of the social and cultural } \\
\text { changes identified by futurists. Kapoor argues that few futurists are } \\
\text { political or social activists and this has limited the influence of } \\
\text { futures work. In other words, 'the best way to predict the future is } \\
\text { to create it' (Rejeski and Olson, 2006, p. 21). }\end{array}$ \\
\hline $\begin{array}{l}\text { Decision-makers are } \\
\text { unable to understand } \\
\text { the implications of } \\
\text { futures work }\end{array}$ & $\begin{array}{l}\text { Glenn et al. (2001, p. } 78 \text { ) find that decision-makers 'do not } \\
\text { understand the complexities of the issues about which they must } \\
\text { decide' and that there is a general lack of understanding of the } \\
\text { magnitude and interdependence of problems. As a result, it can be } \\
\text { difficult for decision-makers to grasp the necessity of actions } \\
\text { proposed by futurists, which leads to a reluctance to act. }\end{array}$ \\
\hline $\begin{array}{l}\text { Decision-makers are } \\
\text { unwilling or unable to } \\
\text { act on futures work for } \\
\text { moral reasons }\end{array}$ & $\begin{array}{l}\text { Glenn et al. (2001) identify eleven individual moral impediments to } \\
\text { foresight action. For example, decision-makers may fail to act on } \\
\text { futures work because they do not care about the wellbeing of } \\
\text { people outside their immediate group (including future } \\
\text { generations), or are corrupt, self-centred or lazy. Hayward (2003) } \\
\text { reviews this list and argues that the moral impediments to foresight } \\
\text { action are the most important barrier to achieving influence } \\
\text { because decision-makers will never act when these impediments } \\
\text { exist, even if all other factors are favourable. Hayward uses } \\
\text { research on moral development to show how the moral } \\
\text { impediments to action exist at particular stages of moral } \\
\text { development but diminish as moral development continues. That is, } \\
\text { the individual capacity for foresight only emerges through a process } \\
\text { of psychological development. Importantly, research indicates that } \\
\text { most individuals are operating from a stage of moral development } \\
\text { at which the moral impediments do indeed exist (Hayward, 2003). }\end{array}$ \\
\hline $\begin{array}{l}\text { Futurists often have a } \\
\text { poor understanding of } \\
\text { their audience }\end{array}$ & $\begin{array}{l}\text { As Kapoor (2001, p. 167) points out, and related to the above point: } \\
\text { 'There is a huge gap between the insights and consciousness of the } \\
\text { futurists, on the one hand, and the consciousness and actions of } \\
\text { ordinary human beings as well as the more powerful decision- } \\
\text { makers, on the other'. Futures work needs to be translated into } \\
\text { terms that resonate with the level of consciousness of the audience } \\
\text { if it is to achieve real traction. }\end{array}$ \\
\hline
\end{tabular}

Table 1: Reasons for the lack of influence of futures work.

\section{Success stories}

Despite the criticisms of the influence of futures work outlined in the previous section, the SOPIFF project did identify cases where futures work has successfully influenced policy. These successes help to deepen understanding of the strategies that futurists can pursue to achieve 
greater influence. In this section, I consider three successful applications of futures work in detail: the application of foresight to science and technology policy; the use of futures thinking to place sustainability concerns on the social agenda; and the development of small-scale, distributed innovations informed by futures thinking.

\subsection{Science and technology foresight}

While foresight and futures studies are seen by some as interchangeable terms, others seek to distinguish the two. For example, Miles and Keenan (2003) argue that foresight is characterised by long-term prospective analysis, close ties to specific decision-making agendas and engagement of networks of influential actors in these agendas. Futures studies, they argue, only displays the first characteristic. Thus foresight is seen as a specific approach within the broader field of futures studies.

The emergence of foresight as an important term and approach is at least partly a strategy employed by futurists to achieve greater policy influence. The term has been popularised in policy circles and more decision-makers are familiar with foresight than with the broader futures studies. This is particularly the case with the application of foresight to science and technology policy. Arguably, science and technology foresight is the area of futures work that has achieved the greatest policy impact over the last decade. For example, Miles and Keenan (2003, pp. 47-48) credit the UK Foresight Programme with raising awareness of foresight concepts and methods and helping to embed foresight practice in 'Government ministries and agencies, Regional Development Agencies, learned societies and industry associations'. Foresight practice in the UK has subsequently spread to the Strategy Unit of the Cabinet Office, which promotes the application of strategic foresight across government.

Science and technology foresight is used by national governments to 'support long-range planning for economic and social policy development' (Calof et al., 2006, p. 2). Countries engaged in this kind of work include Denmark, Japan, Spain, Sweden, the United Kingdom (Cameron et al., 2006; Miles and Keenan, 2003), Ireland, Finland, Canada, Malaysia, Thailand (Wonglimpiyarat, 2007), Vietnam, Korea, China (Schlossstein and Park, 2006), the United States (e.g. the US Hydrogen Roadmap) and several countries in Latin America. Foresight is also applied at a regional level, for example by the APEC Center for Technology Foresight and Foresight for the European Research Area (FORERA).

A Canadian review of international science and technology foresight interviewed practitioners and concluded that:

Their governments believe that there is a necessary link between social and economic policy and planning, between investment in $R \& D$, and in strategic forward planning and engagement processes - specifically citing tools and approaches that fall under the general rubric of science and/or technology foresight (Calof et al., 2006).

Decision-makers are open to science and technology foresight because it is used to maintain or improve national competitiveness in a dynamic technology marketplace. It allows national governments to identify opportunities to develop specialisations that will allow them to compete globally.

Organisations identified by the Canadian review as representing best-practice in the application of science and technology foresight include Forfás in Ireland, the National Institute of Science and Technology Policy (NISTEP) in Japan, the APEC Centre in Thailand, Finnish work by three government agencies and Nokia, and the UK Foresight Programme. These organisations have the following common features: 
- They are 'housed within a ministry responsible for innovation', giving them close access to the policy-making process

- They pursue a clear 'link between foresight and today's policy agenda' and seek to 'develop foresight capacity amongst senior decision makers'

- They have direct 'links to senior policy makers'

- They provide methodologies and skills that are not available in other departments

- They have clear communication strategies

- They all seek to integrate key stakeholders into processes (Calof et al., 2006, pp. 8-9).

The successful examples tend to be close to government, with a clear focus on policy relevance. They apply foresight to a limited set of science and technology issues and tend to employ linear or systemic methods, reducing the complexity that decision-makers need to deal with. As noted by Wynberg (2003, p. 29), science and technology foresight work:

uses few futures concepts as it is concerned with reducing the levels of uncertainty in the future, rather than to open up new alternatives... [It] is currently trapped in the worldviews and filters of the people in power, who rarely consider the outside world of a different set of needs or motivations to their own.

Drawing on Hayward (2003), it is possible to identify reasons for the influence of science and technology foresight. Science and technology foresight does not seek to challenge dominant paradigms. It takes as given the continuing role of the nation-state and national government and seeks to strengthen the position and competitiveness of the nation-state without fundamentally challenging worldviews and related assumptions. By working closely with decision makers and other stakeholders, practitioners of science and technology foresight learn to use language that resonates with decision makers and is less likely to trigger moral impediments to the application of foresight findings. The SOPIFF project identified few examples of science and technology foresight work that greatly extended knowledge or challenged decision makers to develop their moral and cognitive capacities. ${ }^{2}$ As Kapoor (2001) argues in the critique discussed above, science and technology foresight is typically dominated by instrumental rationality and a 'techno-futures' approach, while serving dominant interests and ignoring alternative cultural perspectives. Unfortunately, the success of science and technology foresight seems to be an example of sacrificing quality, breadth and depth of analysis for the sake of influence. This kind of work increases its influence by tailoring the work to the decision-makers, rather than adopting an activist approach.

Is this necessarily a bad thing? At least the limited success of science and technology foresight encourages decision makers to think in the long-term and is helping them to become more familiar with foresight concepts. The question that is still to be answered is whether the successful application of foresight to science and technology policy provides a foundation from which broader and more critical applications of foresight can grow. There is some evidence from the UK Foresight Programme that the initial successful applications within the Office of Science and Technology contributed to the broader application of foresight within the Cabinet Office and across government (Cameron et al., 2006; Miles and Keenan, 2003). Thinking developmentally, it is possible to imagine a process by which futures thinking first becomes more widespread through its narrow application to science and technology decisions before broadening its scope to other decisions and gradually mounting a challenge to dominant 
worldviews. Such an approach would require practitioners to consciously work towards an objective of broader and deeper application of foresight. Even so, such an approach may be too slow to address urgent environmental and social challenges.

\subsection{Futures work and sustainability}

Futures work has also achieved success in helping to place environmental concerns and questions of sustainability firmly on the social agenda. Sustainability is a future-oriented concept. To have a concept of sustainability, we need to think about ways in which long-term future developments might undermine the viability of human society and formulate ways in which the needs of future generations can be met. This means identifying dystopian futures and imagining desirable futures.

Future sustainability is certainly a topic that has exercised the minds of many futurists over the years and futurists can take a great deal of credit for the emergence of environmental awareness and sustainability discourse. Many of the classic publications that drew attention to environmental problems and sustainability are futures works. For example, Rachel Carson's Silent Spring (Carson, 1962), which is often credited with launching the modern Western environmental movement, imagined a future in which no birds sang because of the impacts of chemical pollution. In The Limits to Growth, Meadows et al. (1972) showed how continuing growth in human population and consumption would lead to future overshoot of the Earth's carrying capacity and ecological collapse. The oft-quoted definition of sustainable development from the Brundtland Report, Our Common Future (World Commission on Environment and Development, 1987), explicitly considers the needs of future generations.

A more recent example is the work of the Intergovernmental Panel on Climate Change (IPCC) to put climate change response on the social agenda by documenting possible futures under climate change. Tonn (2007b, pp. 615-617) outlines five ways in which the IPCC can be viewed as a successful transformative initiative:

First, the IPCC is decidedly future-oriented...[and]... is leading a path-breaking effort to make international policy-making more future-oriented. Second, the visibility of the IPCC process is promoting future-orientedness in the general public... Third, the IPCC is building an integrated yet virtual global science "machine" that will benefit futureoriented decision making...Fourth, the IPCC's organization is exquisitely innovative and is perfectly designed to create a virtual research machine and to act as a model for other such efforts. Roughly, its organization resembles a famous description of the World Wide Web, "small pieces loosely joined"... Fifth and last, the IPCC is building a bridge between science and policy.

Tonn (2007b, p. 618) argues that the IPCC is 'helping to transform our conceptions of time and our concerns about the future'. Although the pace of global climate change response remains too slow and the scale of the response remains inconsistent with the scale of the threat, Tonn's paper is a reminder that the efforts of the IPCC are an unprecedented attempt to influence policy using foresight. The IPCC's warnings about the future impact of climate change have been a critical factor in getting climate change onto the policy agenda in most countries and its reports have forced many to think about long-term futures. The IPCC's First Assessment Report and Supplementary Report were 'highly influential on the negotiations of and the final agreement on the [United Nations Framework Convention on Climate Change] in 1992' (Siebenhüner, 2002, p. 416). Indeed, it has been argued that the Framework Convention on Climate Change 'would "certainly not" have been possible without the IPCC' (Agrawala, 1998, p. 639). Subsequent reports are widely used by participants in the public debate about climate change response and have helped to shape the nature of that debate. 
While there is much to criticise about the IPCC's work, including its failure to grapple in a meaningful way with alternative cultural perspectives and its reluctance to make policy or research recommendations (Agrawala, 1998), the breadth of its achievement in keeping climate change on the social and political agenda deserves to be recognised.

Nevertheless, in this and other examples, success in getting sustainability concerns on the social agenda has not been matched by the track record in actually addressing the problems. It is not enough to raise awareness and get issues on the agenda - real and urgent action is needed. Here, futurists come into conflict with vested interests in the political sphere. Kapoor's (2001) argument that futurists need to become politically engaged is nowhere more relevant than in the realm of sustainability policy.

An example of the shape that this political engagement might take is provided by the Great Transition Initiative (GTI) (Raskin et al., 2002; Raskin, 2006a). The GTI is:

an international effort for a transition to a world of enriched lives, human solidarity and a healthy planet. Its long-range global scenarios offer a coherent framework for understanding the current challenges, envisioning alternative futures, and inspiring action. GTI reaches out to concerned citizens everywhere, seeking to raise awareness of the risk and promise of the twenty-first century (GTI website).

More than just an attempt to understand sustainability challenges using futures thinking, the GTI seeks to mobilise a political movement to bring about a transition to a sustainable and desirable future. The GTI has achieved influence in three areas - policy, education and network building:

As policy, the research has been relied on in numerous international assessments, including UNEP's Global Environmental Outlook Series; as education, [it has] brought the [Great Transition] message to scores of audiences world-wide, while [its] literature has been assigned in a growing number of educational settings; as net-working [it is] crystallizing a world-wide group of scholars and activists committed to re-visiting old issues through a [Great Transition] lens while evolving the content of the alternative global scenarios (Paul Raskin, pers.comm., 8 August 2007).

The growing urgency of sustainability challenges and the need to engage with the future to address these challenges presents an opportunity for futures work to achieve greater influence as time goes on. Public and political debate over sustainability, particularly over climate change, puts the future on the agenda and increases familiarity with future concepts. This may become a strong foundation from which social capacity for foresight can grow.

Unlike the science and technology foresight approach, futures work focused on sustainability is more likely to challenge dominant interests and worldviews and has greater potential to confront decision-makers with alternative perspectives that may contribute to their moral development. However, to date, this comes at the cost of policy influence, most likely because this kind of work readily triggers the existing moral impediments in decision makers identified by Glenn et al. (Glenn et al., 2001) and Hayward (2003).

\subsection{Small-scale or distributed futures}

The two previous examples of successes for futures work are on a large scale, seeking influence over critical decisions made by powerful decision-makers. However, I would also argue that one of the real achievements of futures work is in providing inspiration for numerous small-scale, distributed and grassroots initiatives. These initiatives include 
experiments with different ways of living, local or regional planning exercises, workshops that deliver organisational development outcomes and the use of futures thinking for local consciousness raising and movement building.

Kapoor (2007b) collects examples of small-scale transformative initiatives, such as the World Social Forum (Sen, 2007) and Auroville (Kapoor, 2007a), that are bringing the future into the present through experiments with different ways of living. The SOPIFF project also identified many small experiments in different types of living that seek to make alternative futures real. These experiments act as 'lifeboats' or 'seeds' with the potential to grow into desirable futures. By experimenting with alternative ways of organising social systems and cultures, they provide a source of creativity from which new futures can be born. Another way to put this is that people are building prototype or experimental futures in the present to learn what works in practice and how different futures might feel. Perhaps these many small initiatives are a more important contribution for futures work than embedding foresight in existing institutions.

Tonn (2007c) argues for explicit experimentation with different political systems and cultures as a way of trying out different futures. He argues that we should be running as many political and cultural experiments as possible to identify possible sustainable futures. While Tonn calls for an organised and conscious approach, I would argue that this kind of experimentation is already happening on a small scale and unconsciously. Many small initiatives around the world have identified better ways to organise future institutions and have established alternative cultures.

In addition to these futures experiments, futures work often achieves influence through planning exercises and workshops that seek to change thinking within a specific region or organisation. Just two recent examples with which I am familiar include the City of Sydney's Sustainable Sydney 2030 Strategic Plan (SGS Economics and Planning, 2008) and the internal use of futures methods by Melbourne Water in developing a forthcoming wastewater strategy for Melbourne through to 2060. Futures methods have been very influential in both these examples in shaping policies and decisions within a limited realm.

By themselves, these distributed successes for futures work contribute relatively little to addressing the civilisational challenges we face because of their limited scope. However, collectively, they could constitute the foundations of a social movement that can make a much greater contribution to addressing these challenges by making application of social foresight routine. For these distributed initiatives to develop into a broader movement there is a strong need to publicise successful initiatives, draw out lessons about what works in particular contexts and make connections with other initiatives. At present, there appear to be few mechanisms to gather examples of small-scale or experimental futures work together for comparison and evaluation. This may be a rewarding area for future work.

\section{Strategies for increasing influence}

The critiques and success stories considered in the previous sections begin to reveal strategies that futurists can employ to achieve greater influence over policy and praxis. Table 2 identifies strategies associated with each of the reasons for lack of influence identified previously in Table 1. Each strategy is discussed in more detail below.

\begin{tabular}{|l|l|}
\hline Reason for lack of influence & Strategies to increase influence \\
\hline Much futures work is shallow and of poor & Wider application of advanced futures methods, \\
\hline
\end{tabular}




\begin{tabular}{|l|l|}
\hline quality & including critical, layered and integral approaches \\
\hline $\begin{array}{l}\text { Links to specific actions are difficult to } \\
\text { make }\end{array}$ & $\begin{array}{l}\text { Use futures methods with an action focus, such as } \\
\text { backcasting }\end{array}$ \\
\hline $\begin{array}{l}\text { The dominant Western worldview } \\
\text { reinforces short-term thinking }\end{array}$ & $\begin{array}{l}\text { Align futures work with worldview } \\
\text { - Transform worldview to be more receptive to } \\
\text { futures work }\end{array}$ \\
\hline $\begin{array}{l}\text { Futurists do not engage sufficiently with } \\
\text { the political context }\end{array}$ & $\begin{array}{l}\text { Build or contribute to political movements that } \\
\text { seek desirable change }\end{array}$ \\
\hline $\begin{array}{l}\text { Decision-makers are unable to } \\
\text { understand the implications of futures } \\
\text { work }\end{array}$ & $\begin{array}{l}\text { Provide a voice for marginal perspectives } \\
\text { Build individual capacity for understanding and } \\
\text { application of foresight }\end{array}$ \\
\hline $\begin{array}{l}\text { Decision-makers are unwilling or unable } \\
\text { to act on futures work for moral reasons } \\
\text { of their audience }\end{array}$ & $\begin{array}{l}\text { Translate futures concepts into readily } \\
\text { understandable terms }\end{array}$ \\
$\begin{array}{l}\text { Seek to initiate moral development of decision- } \\
\text { makers }\end{array}$ \\
$\begin{array}{l}\text { Translate futures work into terms that } \\
\text { resonate with the moral capacity of the } \\
\text { decision-maker }\end{array}$ \\
$\begin{array}{l}\text { Translate futures work into terms that } \\
\text { resonate with the capacity of the decision- } \\
\text { maker }\end{array}$ \\
\hline
\end{tabular}

Table 2: Strategies for increasing the influence of futures work.

\subsection{Methodological renewal}

Where lack of influence is due to the poor quality of futures work, there is a clear case for methodological renewal. In Table 2, I identify two relevant strategies:

- Wider application of advanced futures methods, including critical, layered and integral approaches, as a way of adding depth and breadth to futures work

- Use of futures methods with an action focus, such as backcasting, to facilitate linkages between futures insights and practical action.

Several authors have identified the need for methodological renewal of the futures field, to move beyond shallow, linear approaches and towards deeper, critical and cultural approaches (Inayatullah, 2002; Slaughter, 2004). For example, Inayatullah's causal layered analysis (Inayatullah, 1998) is a method that digs beneath conventional wisdom to explore the worldviews, discourses, myths and metaphors that shape our present and future. It helps futurists and the people they work with to identify and confront worldview assumptions and open up more creative futures. 
Similarly, the Integral Futures approach (Slaughter, 2008b) encourages futurists to look beyond exterior, systemic trends and into the interiors of individuals and cultures. This approach can open up new insights into possible and probable futures, as well as pointing to strategies for increasing the influence of futures work. Most notably, the Integral perspective reminds us that values and worldviews develop over time and that the people we are trying to influence will be at different points in their developmental journey. This point is taken up in more detail below.

There is little doubt that layered, critical and integral futures methods offer deeper insights into our present situation and the changes needed to bring about desirable futures. However, paradoxically, these methods have the potential to reduce the influence of futures work by increasing its complexity and asking too much of decision-makers. Explicit application of such methods, with decision-makers, can be alienating and contribute to a view of futures work as esoteric and unconnected to everyday reality.

Rather than abandon the insights provided by these methods, futurists who wish to achieve influence may need to use these methods implicitly, in the background. Their insights can then be translated into terms that more readily resonate with the consciousness of decisionmakers. For example, a futurist can use the Integral framework as a mental map to check that all important perspectives are considered while using more conventional methods to actually engage with decision-makers. Futurists that wish to use advanced futures methods directly may need to find ways to 'pitch' them that are appropriate to the audience.

A second strategy that must be part of any methodological renewal is to strengthen the links between futures work and short-term action. There are numerous methodological approaches that explicitly adopt an action focus, including for example backcasting (Dreborg, 1996). The main requirement here is to have a good understanding of the specific political context that a piece of futures work is trying to influence. This makes it more likely that a futurist can identify actions that will be politically palatable while achieving change in a desired direction. The relationship of futures work to the political context is considered in more detail below.

\subsection{The relationship to power}

The relationship between futurists and those who have decision-making power appears to be an important determinant of influence. There are two broad strategies that a futurist can adopt to influence decision-makers. The first is to align futures work with the worldviews of those in positions of power so that it is more likely to achieve acceptance and thereby influence policy. The second is to use futures work to seek transformation of the worldviews held by decision-makers, opening them up to alternative perspectives on the future. This second strategy can be pursued in several ways, including:

- Building or contributing to political movements that seek desirable change as a way of challenging the worldviews of those in power (and perhaps replacing those in power with new decision-makers)

- Providing a voice for marginal perspectives as a way of drawing attention to what is omitted from dominant worldviews

- Seeking to transform the values of individual decision makers (this strategy is discussed in Section 4.3).

The material reviewed during the SOPIFF project indicates that influence has been greatest when futures work is closely linked to policy-makers and decision-makers, particularly when 
the work is directly sponsored or commissioned by decision-makers. Unfortunately, this type of work usually focuses on exteriors, avoiding critique of interior values and worldviews.

Further, it does not usually attempt to fundamentally challenge the paradigms or worldviews of these powerful individuals and organisations. ${ }^{3}$ In other words, it pursues the first strategy listed above, limiting its challenges to those that are likely to be palatable within the dominant worldview. Most science and technology foresight work falls into this camp.

More challenging and critical futures work tends to happen outside the circles of power and has achieved less discernible impact on policies and decisions. Yet this work tends to be of higher quality and complexity, is more likely to adopt layered approaches and is more sensitive to interiors. It is possible that this work is acting as a slow trigger for transformation but impacts are difficult to discern.

A dilemma for the futures field is how to challenge power structures in a way that has political influence. Futurists that work within the state ${ }^{4}$ are more likely to influence policy and decisions but primarily in ways that do not conflict with established interests. As noted by Slaughter (2006, p. 24), 'it is almost impossible to tell the truth from within the conventional ambit of profit and power'. If futurists try to push decision-makers too far or make recommendations that are not politically convenient, they run the risk of losing influence (Glenn et al., 2001). Futurists that work outside the state are less likely to influence policy and decisions but are free to challenge and critique established interests and worldviews and to 'speak truth to power'. Both strategies may have merit.

If we think of the futures community as a social movement that is seeking to influence the policies and decisions of the state, then the work of Dryzek et al. (2003) is useful in understanding the conditions for success. Dryzek et al. (2003) examine the success of social movements in achieving influence within the state. Based on a review of the history of the state, they identify five state imperatives:

- To keep order internally (domestic order)

- To compete internationally (survival)

- To raise the resources to finance the first two tasks

- To secure economic growth (accumulation)

- Legitimation (Dryzek et al., 2003).

These imperatives are the core functions of the state and its reason for existence. When a social movement, such as the futures community, engages with the state in an attempt to alter policies or decisions, Dryzek et al. $(2003$, p. 2 ) argue that its success is highly dependent on 'whether or not it can make a connection to a core state imperative'. Indeed, if a movement cannot connect its concerns to a core state imperative 'then there are systematic limits to what the movement can achieve as a result of its engagement with the state, for, whenever the movement's interest comes up against the core, the movement will lose' (Dryzek et al., 2003, p. 2).

This helps us to understand why certain kinds of futures work readily gain access to the state and influence decision-making. For example, science and technology foresight is closely aligned with the state imperatives to compete internationally and to secure economic growth. 
Further, through involving networks of stakeholders, science and technology foresight helps to provide legitimation for science and technology policy choices.

In contrast, more challenging work that examines long-term sustainability, civilisational futures and values is not readily connected to the existing state imperatives. While it could be argued that sustainability, for example, is critical to support the long-term survival of the state, there is a conflict with the imperative to secure economic growth in the short-term. Thus, sustainability concerns make slow progress in influencing state policies and decisions.

What then does this mean for futurists? What strategies can futurists adopt to achieve greater influence? First, futurists can seek to build familiarity with futures concepts and thinking so that the state imperatives begin to be interpreted as long-term objectives rather than shortterm objectives. Currently, the focus is on short-term competition, growth and resources. Futurists can continue to make it clear that ignoring the long-term puts these short-term imperatives at risk. One way to pursue this is through education and capacity-building, discussed in Section 4.3.

Second, being aware of the five state imperatives can reveal strategies for increasing influence and pushing decision-makers to go further. If the recommendations of futures work can be connected to the state imperatives and avoid conflicting with these imperatives, then their influence will be greater. This is a task of translation and it is a strategy that can be adopted by futurists working inside and outside the state. Thus, futures work can be justified as a way of getting ahead of international competitors, of gaining first access to new markets and of providing legitimation through stakeholder involvement.

Third, and most difficult, is to introduce new state imperatives through a process of transformation. Dryzek et al. (2003) note that the last two state imperatives (accumulation and legitimation) emerged historically in response to social movements that sought transformation of first the authoritarian and later the capitalist state. Thus the critical task for futurists and advocates of sustainability is to seek the introduction of a new state imperative, perhaps defined as long-term sustainability or social foresight. While much can be achieved by translating futures work into terms that connect with existing state imperatives, the ultimate task is to transform the state.

Slaughter (2006) draws on Integral theory to identify five levels through which the capacity for social foresight might develop:

- Level 1: Raw capacities and perceptions of the human brain-mind system

- Level 2: Futures concepts and ideas enable a futures discourse

- Level 3: Futures tools and methodologies increase analytic power

- Level 4: Futures processes, projects and structures embodied in a variety of applications

- Level 5: Social capacity for foresight as an emergent property.

Achieving this staged transformation of state imperatives will require political engagement. For Kapoor (2001, p. 168), 'future studies, or the community of futurists, has to engage much more directly with the political task of creating a democratic future by trying to democratise the global social order in the present'. Likewise, Stevenson (2001, p. 669) points out that: 
On a global basis it becomes obvious that futures studies has to decide quickly whether to engage much more directly with the political task of creating a democratic future by trying to democratise the present global, social order...Then futures needs to learn how to open the dialogue beyond the social sciences and the humanities to include artists, policy makers and scientists.

In other words, the futures community needs to become political and to engage in the task of building a broad-based, creative social movement. Historically, the transformation of state imperatives has only occurred in response to strong social movements (Dryzek et al., 2003). Futurists can provide the vision and momentum for a social movement to either embed longterm thinking within the state or move beyond the centralised state as a way of organising human affairs. The work of the GTI is an excellent example of this approach (Kates et al., 2006; Kriegman, 2006; Raskin et al., 2002; Raskin, 2006a, 2006b). From its starting point in scenario mapping, the GTI has developed into a network of scholars, activists and citizens that seek to establish a vast movement of global citizens. The GTI has used futures work to build a valuesled social movement that seeks to transform state imperatives. Although the influence of this movement to date is small, it will take a sustained effort to achieve transformation of the state and progress may not be immediately evident. The GTI is an exemplar for futures work that seeks to achieve real, transformative influence.

In addition to the task of building a political movement, futurists can continue to draw attention to the omissions from dominant worldviews by providing a voice for alternative futures, drawn from the creativity of those who are currently marginalized or excluded (Kapoor, 2001). For example, Van der Duin et al $(2006$, p. 244) raise the idea of entrusting 'surveys of the future to people in a marginal position who do not identify with any given interest'. This kind of approach can expose the limitations of dominant worldviews and act as an ongoing pressure for transformation.

\subsection{Working with individuals}

The previous section focused on ways that futurists might seek to influence the collective worldview of the state through political engagement. In practice, futurists will often be working to influence particular individuals. One of the clear messages emerging from the work reviewed for the SOPIFF project is the need to build individual capacity for foresight if futures work is to achieve a positive influence on decision making. If, as Hayward (2003) argues, most decision makers are not cognitively and morally equipped to think about the long-term and to act with long-term interests in mind, then no amount of organisational, institutional or political change will bring about more forward-thinking decisions. Conceptually simple futures research will remain the most likely to be acted upon because it will 'accord with the viewpoint of the decision maker' and not trigger moral impediments (Hayward, 2003, p. 8). What is needed then is a concerted effort to equip decision makers with the capacity to consider futures work without triggering 'moral impediments'.

Integral theory identifies two broad strategies that we can pursue in this regard. The first is to translate the findings of futures work into language that resonates with the developmental stage of decision makers. Actions that are desirable from a long-term perspective do not necessarily need to be motivated by a long-term perspective. For example, decision-makers may choose to act on climate change not because of concerns about the long-term viability of human civilisation but because of a desire not to be left out of a growing market. If futurists can understand the motivations of the decision-makers they are trying to influence and identify desirable actions that are consistent with these motivations, then a futures agenda can be pursued by stealth. 
Critical to this approach is developing a strong understanding of the audience and their values and worldviews. Integral theory uses a developmental framework to understand the way values develop over time and the common positions that tend to emerge. However, there are many other approaches to audience segmentation that can be valuable to guide the translation of futures messages for a diverse audience.

Of course, this strategy can only go so far because many future-oriented concepts and desired actions are not so readily translated. This leads to the second strategy, which is to facilitate development of the interior capacity for understanding and application of foresight. There are two distinct ways in which this strategy can be pursued. First, futures work can 'provide some of the energy and impetus for the individual transforming to a higher domain of knowledge' (Hayward, 2003, p. 9). In other words, it can provide a source of psychological disequilibrium that challenges a decision maker to further develop their moral sense. This means contributing to public debate and to decision processes in a way that challenges conventional thinking, seeks to reveal contradictions in worldview assumptions and builds familiarity with foresight and futures concepts among decision-makers. ${ }^{5}$ Gradually, these contributions may help some decision-makers to develop the capacity to understand and act with foresight.

Second, futurists must engage in education at all levels. As noted by Slaughter (2006, p. 10):

The fact remains...that perhaps the single most significant step that society can take to properly equip successive generations for an ever more dangerous and demanding world is, indeed, to help them acquire a modicum of futures, or foresight, literacy.

Futurists need to work to embed futures literacy in school and university curricula and to pursue all opportunities to educate decision makers about futures concepts. In simple terms:

If the decisionmaker(s) lack the knowledge, or do not understand the complexities of the issues about which they must decide, include workshops or training in the research (Glenn et al., 2001, p. 179).

As part of an education strategy, futures work can seek to expand the area of knowledge that a decision maker is aware of, without necessarily triggering moral impediments. This could lead to better decisions and better policy.

Beyond the task of building the capacity of decision makers for foresight, futures practitioners must also seek to build their own capacity for foresight and their ability to translate futures work into terms that resonate with people at all stages of development.

\subsection{The role of participation}

The final issue I wish to examine is the role of participation in improving the influence of futures work. Based on this review, the potential for futures work to achieve influence appears to increase when the views of multiple stakeholders are sought and genuinely included using appropriate futures methods and processes. We can understand this in broad terms by referring to the state imperatives discussed in Section 4.2. A process that involves a broad range of stakeholders is more likely to be perceived as legitimate, connecting it more closely to the state imperative of legitimation. However, it is worth considering in more detail the ways in which participation can deliver greater influence.

First, involving more participants provides access to more discourses and worldviews and leads to a more comprehensive map of possible and desirable futures. Kapoor (2001) argues for a focus on alternative futures and this means bringing in non-Western perspectives and other 
perspectives from the margins. Including voices from the margins helps futurists to identify weak signals that may develop into important future drivers (van der Duin et al., 2006).

Second, a process that genuinely includes more perspectives has greater potential for creativity in its visioning. This comes about through the simple inclusion of more people with different values, which is an excellent resource for futures work. It also comes about through creative contestation and discourse between people with different values.

Third, and most closely linked to the legitimation imperative, involving more stakeholders provides a sense of ownership, particularly for those that will need to implement any recommendations. Glenn et al. (2001, p. 180) recommend that futurists:

Include diverse interest groups and key actors in the research process to make sure that all understand how a contemplated decision may affect stakeholders, and to reduce subsequent political impediments. Enlist the support of people in this process who will use or be affected by the activity.

Finally, in science and technology foresight processes, public participation may offer a pathway towards greater democratic control over technology, as recommended by Kapoor (2001). The literature on deliberative democracy indicates that inclusion of ordinary citizens in decisionmaking processes leads to decisions that are more likely to reflect the public interest. Thus, we can expect that genuine inclusion of ordinary citizens in decisions about technology development may result in a curb on development of some of the more alarming technologies.

\section{Conclusions}

Futures work is currently falling well short of its potential to achieve influence over public policy and practice, and thereby contribute to a transition to a sustainable society. Much futures work remains shallow, focused on linear trends and lacking depth. Some futures work fails to achieve influence because it gives too little attention to how its insights can be translated into concrete actions. However, most futures work fails to achieve influence because it runs up against a dominant Western worldview in which short-term thinking is entrenched. To overcome this barrier to influence, futurists need to become politically engaged in the critical task of developing or contributing to new social movements. At the same time, futurists need to understand their audience better and to work to translate their findings or transform their audience.

The SOPIFF review indicates that futures work within the state has done too little to include alternative views, is dominated by "techno-futures" and primarily serves the interests of the state, defined to include both government and corporate interests. On the other hand, higher quality futures work outside the state has failed to engage adequately with the political process and, as a consequence, remains marginal to the key policies and decisions that shape human society.

There have been some qualified successes. Science and technology foresight is now a well established approach that has real influence on public policy. However, its scope is narrow and it does not address civilisational challenges in any detail. Futures work has also made a major contribution to placing issues of environmental impact and sustainability on the social agenda, but too little progress has been made in addressing these issues through policies and actions. Small-scale futures initiatives have experimented with different futures and achieved local influence but have not altered the disastrous direction of human civilisation. 
I have explored several strategies that futurists could pursue to achieve greater influence.

First, futurists need to continue to pursue methodological renewal to improve the depth and criticality of futures work. The use of advanced futures methods, including critical methods, layered approaches and Integral futures approaches, is at the heart of this methodological renewal. However, futurists need to remember that the audience may not be ready for explicit application of these approaches; they will likely need to remain implicit, in the background. Second, futures work can only achieve real influence by translating its findings and recommendations into terms that either connect with existing state imperatives or contribute to the eventual transformation of state imperatives. Most futures work fails to achieve influence because it is not aware of and responsive to this political reality. Third, the individual cognitive and moral capacity of many decision-makers is not adequate to the task of seriously engaging with the future. As demonstrated by Hayward (2003), futures work often triggers moral impediments for decision-makers that prevent them taking action. Finally, the failure to include influential stakeholders and alternative voices in futures work can limit its potential for influence.

From an Integral perspective, two clear strategies for increasing influence become apparent: translation and transformation. The first strategy requires the translation of futures concepts, findings and recommendations into terms that connect with state imperatives and are appropriate to the cognitive and moral stage of decision-makers. There are often multiple motivations for taking a particular action and futurists could achieve a lot more by identifying and emphasising the motivations that are of most interest to decision-makers. However, the strategy of translation will ultimately run into limitations, as many futures concepts are not easily translated in this way and the incremental changes that are likely with this approach will be too slow to avert disaster.

The second strategy is more difficult but has much greater potential to deliver lasting change. It requires futurists to consciously engage with the task of transforming individual decision makers and ultimately state imperatives through critique and political engagement. As Slaughter (2006, pp. 25-26) puts it:

there is no solution to the challenges facing Australia and the world unless people are prepared to look freshly on embedded assumptions and tackle deep-seated social, political and economic dysfunctions. Another way of putting this is to say that there is no way forward without intelligent critique.

Futurists need to apply critical and integral methods to look more deeply at human society and highlight the contradictions, values and worldviews that underpin the worrying direction of human civilisation. However, it is not enough to critique from a distance. Futurists must use this critique as a foundation to build social and political movements that challenge the assumptions of the state and seek legitimacy for sustainability and the forward view. They must use their work as a source of disequilibrium for decision-makers, with the potential to initiate interior reassessment and transformation. They must engage in public debate and act as leaders by providing a vision to guide broader movements. If futurists do not engage in this way, then futures studies will remain on the periphery of society, watching as civilisation crumbles.

\section{Acknowledgements}

I would like to acknowledge the Foundation for the Future for providing the funding for the SOPIFF project. I would also like to acknowledge Richard Slaughter for his leadership of the 
project and my fellow researchers - Maree Conway, Dennis Morgan and Graham May - for their valuable contributions to the project and to the thinking expressed in this paper.

\section{References}

Agrawala, S. (1998), "Structural and process history of the Intergovernmental Panel on Climate Change", Climatic Change, Vol. 39 No. 4, pp. 621-642.

Calof, J., Tanguay, D. \& Spring, L. (2006), "Addressing Canada's foresight capacity: A report to the National Science Advisor", Science and Technology Foresight Directorate, Office of the National Science Advisor, Government of Canada, 15 September.

Cameron, H., Georghiou, L., Keenan, M., Miles, I. \& Saritas, O. (2006), "Evaluation of the United Kingdom Foresight Programme: Final Report", PREST, Manchester Business School, University of Manchester, March.

Carson, R. (1962), Silent Spring, Houghton Mifflin, Boston.

Dreborg, K.H. (1996), "Essence of backcasting", Futures, Vol. 28 No. 9, pp. 813-828.

Dryzek, J.S., Downes, D., Hunold, C., Schlosberg, D. \& Hernes, H.-K. (2003), Green states and social movements: Environmentalism in the United States, United Kingdom, Germany, and Norway, Oxford University Press, New York.

Glenn, J.C., Gordon, T.J. \& Dator, J. (2001), "Closing the deal: How to make organizations act on futures research", Foresight, Vol. 3 No. 3, pp. 177-189.

Hayward, P. (2003), "Resolving the moral impediments to foresight action", Foresight, Vol. 5 No. 1, pp. 4-10.

Inayatullah, S. (1998), "Causal layered analysis: Poststructuralism as method", Futures, Vol. 30 No. 8, pp. 815-829.

Inayatullah, S. (2002), "Layered methodology: meanings, epistemes and the politics of knowledge", Futures, Vol. 34 No. 6, pp. 479-491.

Institute for Alternative Futures (2005), "The 2029 project: Achieving an ethical future in biomedical R\&D", Institute for Alternative Futures, Alexandria, Virginia.

Kapoor, R. (2001), "Future as fantasy: Forgetting the flaws", Futures, Vol. 33 pp. 161-170.

Kapoor, R. (2007a), "Auroville: A spiritual-social experiment in human unity and evolution", Futures, Vol. 39 No. 5, pp. 632-643.

Kapoor, R. (2007b), "Transforming self and society: Plural paths to human emancipation", Futures, Vol. 39 No. 5, pp. 475-486.

Kates, R., Leiserowitz, A. \& Parris, T. (2006), "Great transition values: Present attitudes, future changes", GTI Paper Series: Frontiers of a Great Transition, Paper \# 9, Tellus Institute, Boston.

Kriegman, O. (2006), "Dawn of the cosmopolitan: The hope of a global citizens movement", GTI Paper Series: Frontiers of a Great Transition, Paper \# 15, Tellus Institute, Boston. 
Meadows, D.H., Meadows, D.L., Randers, J. \& Behrens, W.W. (1972), The Limits to Growth, Universe, New York.

Miles, I. \& Keenan, M. (2003), "Two and a half cycles of foresight in the UK", Technikfolgenabschatzung - Theorie und Praxis, Vol. 2 No. 12, pp. 41-49.

Ramos, J.M. (2004), "Foresight Practice in Australia: A Meta-Scan of Practitioners and Organisations", Australian Foresight Institute.

Raskin, P., Banuri, T., Gallopin, G., Gutman, P., Hammond, A., Kates, R. \& Swart, R. (2002), "Great transition: The promise and lure of the times ahead", Stockholm Environment Institute, Boston.

Raskin, P.D. (2006a), "The great transition today: A report from the future", GTI Paper Series: Frontiers of a Great Transition, Paper \# 2, Tellus Institute, Boston.

Raskin, P.D. (2006b), "World lines: Pathways, pivots and the global future", GTI Paper Series: Frontiers of a Great Transition, Paper \# 16, Tellus Institute, Boston.

Rejeski, D. \& Olson, R.L. (2006), "Has futurism failed?", The Wilson Quarterly, No. Winter 2006, pp. 14-21.

Schlossstein, D. \& Park, B. (2006), "Comparing recent technology foresight studies in Korea and China: Towards foresight-minded governments?", Foresight, Vol. 8 No. 6, pp. 48-70.

Sen, J. (2007), "The World Social Forum as an emergent learning process", Futures, Vol. 39 No. 5, pp. 487-504.

SGS Economics and Planning (2008), "Sustainable Sydney 2030: City of Sydney Strategic Plan, Final Consultation Draft", City of Sydney, Sydney.

Siebenhüner, B. (2002), "How do scientific assessments learn? Part 1. Conceptual framework and case study of the IPCC", Environmental Science and Policy, Vol. 5 No. 5, pp. 411-420.

Slaughter, R.A. (2002), "Futures studies as a civilizational catalyst", Futures, Vol. 34 No. 3-4, pp. 349-363.

Slaughter, R.A. (2004), Futures beyond dystopia: Creating social foresight, RoutledgeFalmer, London and New York.

Slaughter, R.A. (2006), "Pathways and impediments to social foresight", Strategic Foresight Program Monograph Series, Volume 10, Swinburne University.

Slaughter, R.A. (2007), "Why is the future still a 'missing dimension'?", Futures, Vol. 39 pp. 747754.

Slaughter, R.A. (2008a), "Asleep at the wheel: The world future society at forty", Futures, Vol. 40 No. 1, pp. 91-101.

Slaughter, R.A. (2008b), "What difference does 'integral' make?", Futures, Vol. 40 No. 2, pp. 120-137. 
Slaughter, R.A. (2009), "The State of Play in the Futures Field: An Introduction and Overview", Foresight.

Stevenson, T. (2001), "The futures of futures studies", Futures, Vol. 33 pp. 665-669.

Tonn, B. (2007a), "Determinants of futures-oriented environmental policies: A multi-country analysis", Futures, Vol. 39 No. 7, pp. 773-789.

Tonn, B. (2007b), "The Intergovernmental Panel on Climate Change: A global scale transformative initiative", Futures, Vol. 39 No. 5, pp. 614-618.

Tonn, B.E. (2007c), "Futures sustainability", Futures, Vol. 39 No. 9, pp. 1097-1116.

van der Duin, P., Hazeu, C., Rademaker, P. \& Schoonenboom, J. (2006), "The future revisited: Looking back at The Next 25 Years by the Netherlands Scientific Council for Government Policy (WRR)", Futures, Vol. 38 No. 3, pp. 235-246.

Wonglimpiyarat, J. (2007), "National foresight in science and technology strategy development", Futures, Vol. 39 No. 6, pp. 718-728.

World Commission on Environment and Development (1987), Our common future, Oxford University Press, New York.

Wynberg, A. (2003), "Wider and deeper: A review and critique of science and technology foresight exercises in the 1990s", Strategic Foresight Program Monograph Series, Volume 3, Swinburne University.

\section{Endnotes}

\footnotetext{
${ }^{1}$ The Integral meta-scanning framework is described by Slaughter in this issue (Slaughter, 2009). I have not reproduced that description here but I do use some terms from the framework in this paper, so I would encourage the reader to read Slaughter's paper first or the original outline of the method in Ramos (2004).

2 The 2029 Project: Achieving an Ethical Future for Biomedical R\&D, a project run by the Institute for Alternative Futures, is an honourable exception (Institute for Alternative Futures, 2005). While focused on biomedical research and development, the project developed an ethical and integrative vision that clearly challenged many of the participants to deepen their thinking.

${ }^{3}$ It could be argued that the IPCC is an exception, as it does pose a challenge to mainstream interests. However, I would argue that the IPCC's message is posed in such a way as to avoid a fundamental challenge to worldview commitments. While it points to the need for change, it avoids the question of whether that change needs to be deep cultural change or merely technological and institutional change. This leaves powerful interests with plenty of room to pursue technological solutions and incremental changes in institutions that are not commensurate with the scale of the problem.

${ }^{4}$ The term 'state' is used in this paper to refer to the centralised power structures that continue to shape the direction of modern civilisation. Like Dryzek et al. (2003), I am in no way committed to centralised power structures but merely recognising that the state is still hugely important in determining the prospects for social movements. As they note, a successful response to the civilisational challenges we face may require a withering and distributing of state power but it must start by engaging or seeking to replace existing power structures.
} 
${ }^{5}$ Contributing to public debate is one of four strategies identified by Kapoor (2001). 
This article is (c) Emerald Group Publishing and permission has been granted for this version to appear here (http://epress.lib.uts.edu.au/research/handle/10453/10322). Emerald does not grant permission for this article to be further copied/distributed or hosted elsewhere without the express permission from Emerald Group Publishing Limited.' 